\title{
The Increasing of Quality Biogas before to Compression and Bottling Techniques (Case Study in Ngentak Village, Bantul, DIY, Indonesia)
}

Suhascaryo, KRT Nur ${ }^{1}$, Prianto, Sugeng ${ }^{2}$., Purnomo, Hadi ${ }^{3}$, Mispawanti, RR Hasthi N ${ }^{4}$.

\begin{abstract}
This paper aims to explain a project which designed a system to compress and store the biogas in such a way that it will be suitable for cooking gas in rural communities, especially in Ngentak Village, Poncosari, Bantul, DIY Province in Indonesia. After water content and $\mathrm{CO} 2$ have been removed from biogas methane from digester by Diethylen Glycol and Natrium Hydroxide ( $\mathrm{NaOH}$ ), water has to be reduced until 2.5 ml by $15 \mathrm{ml}$ of glycol content and $\mathrm{NaOH} 30 \%$ to reduce $1.34 \%$ of $\mathrm{CO} 2$ content and $94.59 \%$ of gas methane. In addition, biogas compression and bottling process consist of different steps such as biogas purification $\left(\mathrm{H}_{2} \mathrm{O}\right.$ and $\mathrm{CO}_{2}$ removal unit), compression and bottling. As a result, this study has succeeded in compressing biogas into $8,78 \mathrm{lbs}$ and LPG cylinder reaching maximum level in pressure gauge.
\end{abstract}

Keywords—biogas, compression, bottling

\section{Introduction}

Biogas is a renewable fuel produced from waste treatment since biogas is a mixture of methane $(\mathrm{CH} 4)$, carbon dioxide (CO2), hydrogen sulphide and traces of water vapor. It is generated when bacteria degrades biological material in the absence of oxygen in a process known as anaerobic digestion which is basically a simple process carries out in a number of steps by many different bacterias that can use almost any organic material as a substrate - it occurs in digestive systems, marshes, rubbish dumps, septic tanks and the Arctic Tundra.

In addition, biogas is a gas produced from organic materials such as animal manure, human excreta, kitchen remains, crops straws and leaves after decomposition also fermentation under air tight (no oxygen) condition, as well as main products of the anaerobic digestion which are biogas and slurry. Biogas digester is used to collect kitchen wastes and convert it to biogas through anaerobic digestion processes.

\footnotetext{
${ }^{1}$ Suhascaryo, KRT Nur.
}

Universitas Pembangunan Nasional "Veteran" Yogyakarta Indonesia

${ }^{2}$ Prianto, Sugeng.

Universitas Pembangunan Nasional "Veteran" Yogyakarta Indonesia

${ }^{3}$ Purnomo, Hadi.

Universitas Pembangunan Nasional "Veteran" Yogyakarta Indonesia

${ }^{4}$ Mispawanti, RR Hasthi N

Universitas Gadjah Mada Yogyakarta

Indonesia
Biogas is a clean-burning, renewable fuel that contains $50-60 \%$ methane and it can be used in household cooking applications[1]. After extraction of biogas (energy), the slurry comes out of the digester as a by-product of the anaerobic digestion system. The biogas burns very well when the $\mathrm{CH} 4$ content is more than $50 \%$ and therefore biogas can be used as a substitute for kerosene, charcoal and fire wood for cooking and lighting[2]. Look at the table 1 below depicts the detailed composition of biogas [3].

TABLE II. DETAILED COMPOSITIONS OF BIOGAS

\begin{tabular}{|c|c|}
\hline Substances & Biogas \% \\
\hline Methane $\left(\mathrm{CH}_{4}\right)$ & $50-60$ \\
\hline Carbon Dioxide $\left(\mathrm{CO}_{2}\right)$ & $34-38$ \\
\hline Nitrogen $\left(\mathrm{N}_{2}\right)$ & $0-5$ \\
\hline Oxygen $\left(\mathrm{O}_{2}\right)$ & $0-1$ \\
\hline Water Vapour $\left(\mathrm{H}_{2} \mathrm{O}\right)$ & 6 \\
\hline Hydrogen Sulphide $\left(\mathrm{H}_{2} \mathrm{~S}\right)$ & Trace \\
\hline
\end{tabular}

The aim of the project is to design a system to compress and store biogas in such a way that it will be suitable for cooking gas in rural communities. This research is focused on energy conservation area in Srandakan, Bantul, DIY (see fig. 1).

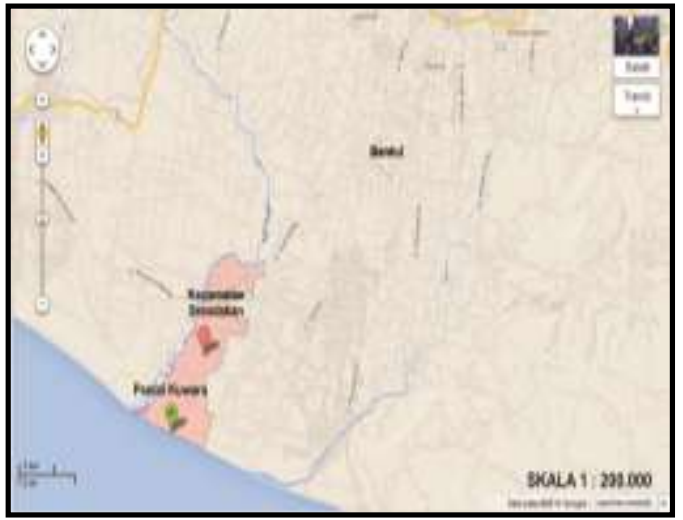

Figure 1. Research area in Srandakan, Bantul, DIY Province

\section{Proposed Method}

The biogas compression and bottling process consist of different steps such as biogas purification $\left(\mathrm{H}_{2} \mathrm{O}\right.$ and $\mathrm{CO}_{2}$ removal unit), compression and bottling (see fig 2). 


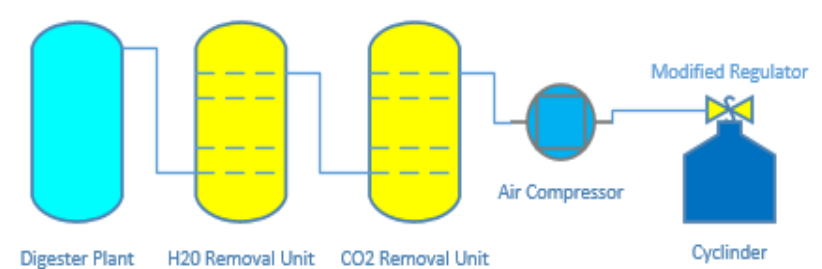

Figure 2. Typical arrangement of biogas compression and bottling process

The proposed methods as depicted in figure 2 consist of:

1. Biogas digester plant

2. $\mathrm{H}_{2} \mathrm{O}$ and $\mathrm{CO}_{2}$ removal unit

3. Compressor unit

4. Storage unit (modified regulator \& cylinder)

The biogas digester plant has been defined to capture gas methane from ranch cow raw waste material, to influx dehydrator removal by diglycol or DET so that reducing water content, and to capture ethylene $\mathrm{CO} 2$ by $\mathrm{CO} 2$ removal with natrium hidroxide $(\mathrm{NaOH})$. The next step result of gas methane is to compress by compressor unit in blue tube 8.75 lbs.

The raw biogas from the digester is first allowed to pass through a set of two scrubbing units for removal of impurities as shown in figure 2. The methane rich content biogas is now allowed to compress by passing it through a compressor (about 50-70 psi). The compressed gas is finally stored into small cylinders with the help of modified regulator and adapter. Gas cylinder is connected to one output port in regulator where a pressure gauge is connected to the other output port. The reverse flow of the biogas is avoided by non-return valve in cylinder. For purification system, it can be seen in previous research on purification and improvement of quality biogas from result installation of biogas making process in Ngentak Village, Poncosari, Bantul, DIY Province[4].

\section{Result and discussion}

Dehydrator unit by Diethylen Glycol (DET) was optimized to reduce $2.5 \mathrm{ml}$ water content by $15 \mathrm{ml}$ of DET and $\mathrm{CO} 2$ removal optimized in $31 \%$ was reduced to $1.34 \%$ by $30 \%$ concentration of $\mathrm{NaOH}$ and $94.59 \%$ biogas methane content. Using $\mathrm{NaOH}$ to reduce $\mathrm{CO} 2$ content impacted a problem in plant, especially in valve. The problem was occured in any solid $\mathrm{Na} 2 \mathrm{CO} 3$ in reactor (see Tab. II)

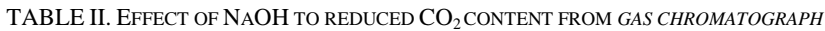

\begin{tabular}{|c|c|c|}
\hline \multirow{2}{*}{$\begin{array}{c}\text { Add } \mathbf{( \% )} \\
\text { (\%) }\end{array}$} & \multicolumn{2}{|c|}{ Results of gas chromatograph } \\
\cline { 2 - 3 } & $\mathbf{C H}_{\mathbf{4}}(\boldsymbol{\%})$ & $\mathbf{C O}_{\mathbf{2}}(\boldsymbol{\%})$ \\
\hline 0 & 52.642 & 30.36 \\
\hline 10 & 75.74 & 11.094 \\
\hline 30 & 94.585 & 1.344 \\
\hline
\end{tabular}

Similar researches on compression and biogas containment has been done in several places. The storage of biogas may also be a problem, as it is always with gaseous products. Biogas could not be stored easily, as it did not liquefy under pressure at ambient temperature. Its critical temperature and pressure are $-82.5^{\circ} \mathrm{C}$ and 47.5 bars. Compressing the biogas reduces the storage requirements, offers concentrated energy content and gives pressure to overcome the resistance to gas flow. Most commonly used biogas storage option is in propane or butane tanks and commercial gas cylinders up to 200 bars. Depending on the application of biogas (e.g. vehicle fuel, domestic cooking) the storage facilities are varried[5]. The purified and dried biogas was compressed into an LPG cylinder by using a refrigerant reciprocating compressor up to an absolute pressure of 5 bars in total of 12-14 minutes[2].

Other studies show that the longer time to fill the cylinder with constant compressor pressure, the more mass of gas is filled and the greater the pressure of the gas in the gas cylinder which can be seen in the pressure gauge[6]. The methane compression and storage system in the tube cannot be done indiscriminately, but it needs more in-depth study because methane includes non-condensable gas, it cannot immediately turn into liquid even to extreme pressures and temperatures, unlike LPG that turns into liquid at not too high pressures, approximately 8 atm at room temperature. In addition to that, a non-condensable gas such as methane, by its combustible properties, is going to increase its temperature if there is given pressure. This can increase the risk of explosion during compression process, so the safety considerations should take precedence. Excessive pressure also allows gas leakage during storage. It is very dangerous to try to store methane in gas cylinders on the market because it is not designed to ensure the safety of the storage of methane[7]. This study has succeeded in compressing biogas into $3 \mathrm{~kg}$ and $12 \mathrm{~kg}$ LPG cylinder reaching maximum level in pressure gauge. In $3 \mathrm{~kg}$ gas cylinder, the biogas can be used for approximately six minutes.

\section{Conclusions}

Below are three main conclusions that can be concluded. a. Biogas can be compressed into LPG tubes with modified regulators before treatment plant.

b. The longer the biogas fills into the gas cylinder (tube) the more mass of biogas and the greater the gas pressure in the gas cylinder (tube).

c. The methane compression and storage system in the tube cannot be done indiscriminately, but it needs more in advanced study because methane includes non-condensable gas.

\section{v. Recommendation}

Future research may be conducted on the study of : a. It needs the right technology to pack the biogas in a tube safely and standardized.

b. Economics of the biogas product vs LPG in market. c. Marketing models to develop biogas tubes market. 


\section{References}

\section{Printed}

[1] Virendra K. Vijay, Ram Chandra, Parchuri M. V. Subbarao and Shyam S. Kapdi. "Biogas Purification and Bottling into CNG Cylinders: Producing Bio CNG from Biomass for Rural Automotive Applications". Mechanical Engineering Department, Indian Institute of Technology, Delhi, Hauz khas, New Delhi, India, 2000.

[2] Nallamothu, R. B., Teferra A, and Rao, B. V. A., Biogas Purification, Compression and Bottling", Marine Engineering Department, College of Engineering, Andhra University, India, Global Journal of Engineering, Design \& Technology, Vol. 2 (6): 34 38, 2013.

[3] Vinayak R. Gaikwad, Dr. P. K. Katti., "Bottled biogas; A future source of renewable energy", Department of Electrical engineering, Dr BATU, Lonere, Maharashtra, 2014.

[4] Suhascaryo, N., Purnomo, H., Priyanto, S., and Prastyo, H. B., "Purification and Improvement of Quality Biogas From Result Installation of Biogas Making Process in Ngentak Village Poncosari District Of Bantul Regency", National Development "Veteran" University of Yogyakarta, 2016.

[5] Demirbas, M. F, Balat, M., "Recent Advances on The Production and Utilization Trends of Biogas Fuels: A Global Perspective", Science Direct, 2016.

[6] Putra, W. T., Fadelan, Munaji., "Analisa Hasil Penyimpanan Energi Biogas Ke Dalam Tabung Bekas", Seminar Nasional Inovasi Dan Aplikasi Teknologi Di Industri (Seniati), ISSN : 2085-4218, 2016.

\section{Online}

Ika, UGM Kembangkan Tabung Biogas., 2014

https://www.ugm.ac.id/id/berita/8908 ugm.kembangkan.tabung.biogas

About Author (s):

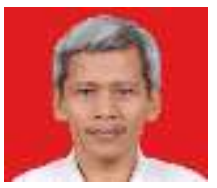

KRT Nur Suhascaryo is currently a lecturer in Faculty of Mineral Technology, Universitas Pembangunan Nasional "Veteran" Yogyakarta, Indonesia. He had his master and doctoral degree from Bandung Institute of Technology, Indonesia.

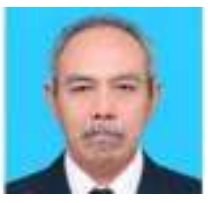

Sugeng Prianto is currently a lecturer in Faculty of Agriculture, Universitas Pembangunan Nasional "Veteran" Yogyakarta, Indonesia. He had his master degree from Universitas Gadjah Mada, Indonesia. Meanwhile, his bachelor degree from Universitas Sebelas Maret, Indonesia.

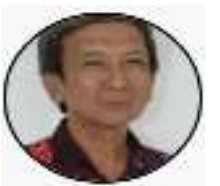

Hadi Purnomo is currently a lecturer in Faculty of Mineral technology, Universitas Pembangunan Nasional "Veteran" Yogyakarta, Indonesia. He had his master degree from Universitas Gadjah Mada Yogyakarta, Indonesia. Meanwhile, his bachelor degree had been accomplished from Universitas Indonesia, Indonesia.

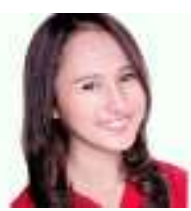

RR Hasthi Nuroktriana Mispawanti is currently pursuing her master degree in Master and Doctoral Program Faculty of Economics and Business, Universitas Gadjah Mada Yogyakarta, Indonesia. She had her bachelor degree majoring English Literature in the same university. 